Review

\title{
Can public awareness, knowledge and engagement improve climate change adaptation policies?
}

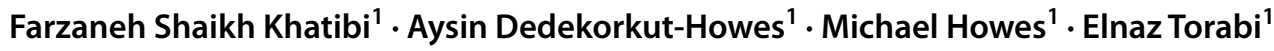

Received: 3 December 2020 / Accepted: 25 February 2021

(C) The Author(s) 2021 OPEN

\begin{abstract}
Communities that are vulnerable to the impacts of climate change need to adapt to increase their resilience. Effective government policies and plans are a key component of this transition, but they are not sufficient in themselves. The community needs to be made aware of the risks, acquire knowledge about the options that are available for a response, and be empowered to take their own actions. Effective public engagement is therefore key to success in planning for climate change. This paper focuses on the importance of public engagement in climate change adaptation policy. It undertakes a systematic quantitative review of the literature dealing with the core themes of climate change awareness, knowledge, and engagement in policy-making. The findings reveal a gap in the existing academic literature on public engagement, its impacts on different types of knowledge, and the integration of both into climate change adaptation policy. In addition, findings show a strong link between public knowledge and engagement that can be used to encourage and motivate the public by using behavioural economics as a policy instrument. The paper also makes a useful contribution by identifying more effective strategies to improve climate change resilience and sustainability.
\end{abstract}

Keywords Public involvement - Citizen participation · Local and traditional knowledge · Policy cycle · Systematic quantitative literature review

\section{Introduction}

Climate change has become one of the key drivers in many natural disasters. The Intergovernmental Panel on Climate Change (IPCC) has drawn attention to the impacts of climate change being felt across the world in the form of events such as floods, rising sea levels, storms, droughts, heatwaves, bushfires, etc. [1]. Climate change poses a major challenge for policy-makers and governments need to generate broad public support for an effective response [2-5]. Raising public awareness and knowledge of the risks amongst residents in vulnerable communities is therefore crucial [6]. The Productivity Commission [7] (p.5) describes effective climate change adaptation as "actions that enhance community wellbeing" where wellbeing includes economic factors such as income, wealth and consumption as well as quality of life factors such as health, environmental amenity, leisure, community participation, and political rights and freedoms. Owen [8] measures effectiveness of climate change adaptation using five indicators: reducing risk and vulnerability, developing resilient social systems, improving the environment, increasing economic resources, and enhancing governance and institutions.

Mitigation and adaptation are two complementary strategies for addressing climate change [1]. Whereas mitigation aims to reduce the drivers of climate change by cutting greenhouse gas emissions, adaptation aims to build resilience to the impacts that cannot be avoided [9]. Many studies suggest that public engagement has a vital role to play in both

Aysin Dedekorkut-Howes, a.dedekorkut@griffith.edu.au | ${ }^{1}$ Cities Research Institute, Griffith University, Brisbane, Australia. 
mitigation and adaptation [10-13]. There are, however, different approaches to public engagement that vary from topdown public education programs to bottom-up stakeholder decision-making.

Although the relationship between the stakeholders' attitude, knowledge, and engagement is acknowledged in the broader literature [14], the nature of this relationship is unclear, particularly in the context of climate change policy. This paper focuses on this relationship and addresses the research question: "How can public awareness, knowledge, and engagement improve climate change adaptation policy?" A systematic quantitative literature review (SQLR) was conducted to identify the emerging themes, the main points of contention, and research gaps that are most relevant to the role of public engagement in the climate change policy development and decision-making processes.

The paper first provides a theoretical framework incorporating knowledge types, public engagement, and the policy cycle. It then outlines the methodology of the study, followed by the results of the systematic literature review and discussion of the key findings. The paper concludes with a summary of the key points.

\section{Theoretical framework}

Policy-making and public engagement are complex processes. To approach the review systematically and identify the key themes, a theoretical framework consistent with the research question is utilised. This framework shows all stages of the climate policy cycle and their relationship with two important elements of this study: the levels of public participation and the types of knowledge (Fig. 1). As the theoretical framework centres on these two elements and their interaction with the climate policy cycle's stages [15], particularly policy instruments to improve climate adaptation action, the concepts of public participation and engagement, policy cycle, and knowledge types are introduced first.

\subsection{Public participation}

Public participation refers to various types of activities that are used to incorporate people's interests, concerns, needs, and values into decisions and actions on public issues $[16,17]$. The main focus of this study is on the direct and active forms of participation in which citizens are actively engaged in making decisions to find solutions to problems, as

Fig. 1 Theoretical Framework

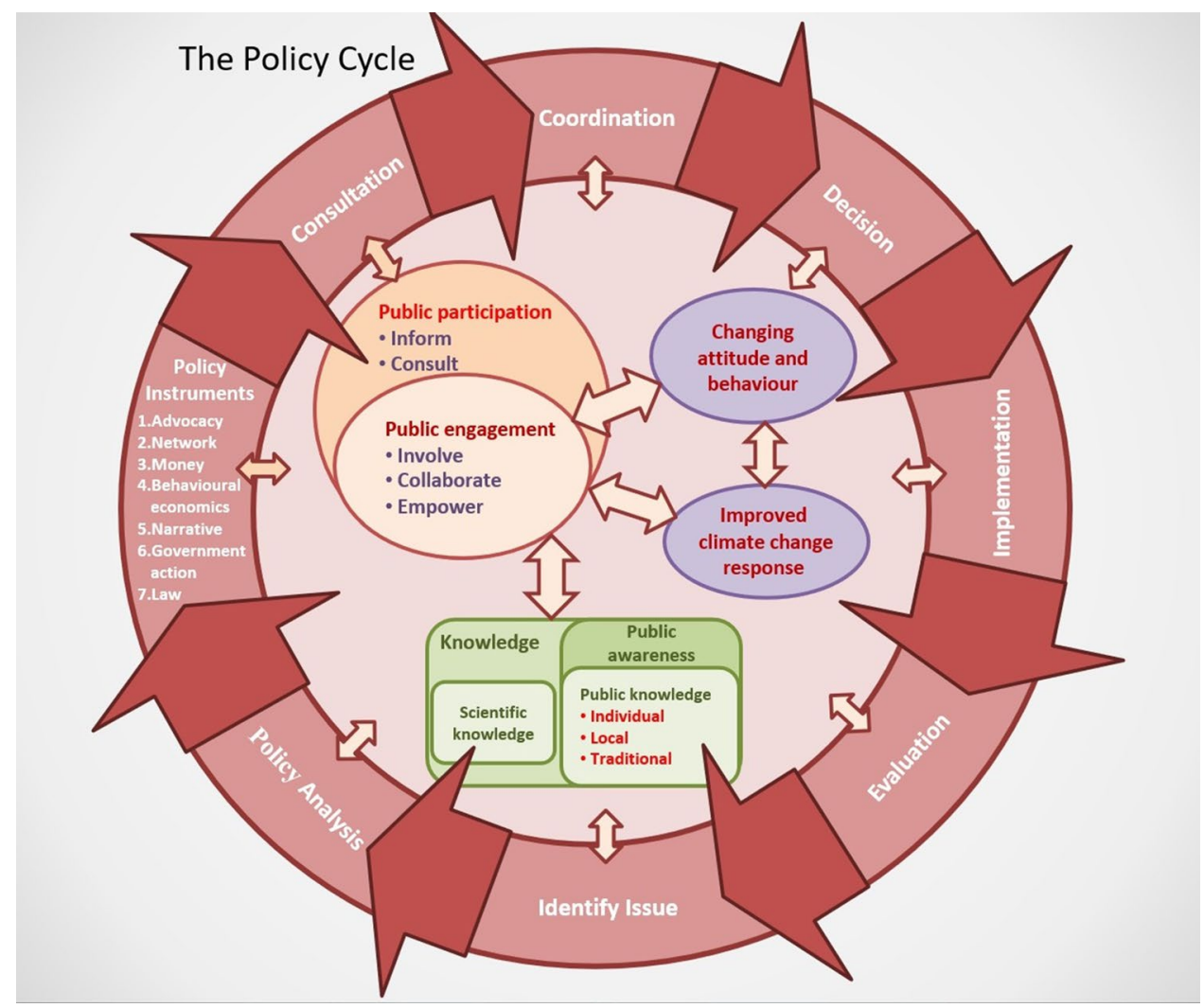


opposed to indirectly participating in the decision-making process (e.g. through voting for representatives or dedicating money to their preferred candidates) [17]. It is important to note that a series of related terms such as citizen/community/ public participation/engagement/involvement/empowerment are used (sometimes interchangeably) by policymakers and researchers.

There are various typologies of public engagement. Arnstein's [18] ladder of citizen participation ranks different levels of participation from non-participation to citizen power. Alternative typologies to Arnstein's ladder have been offered. More recently the International Association for Public Participation (IAP2) [19] has developed a public participation spectrum and identified the five main levels as informing, consulting, involving, collaborating, and empowering citizens (Table 1). The level of public impact increases with each level of the IAP ${ }^{2}$ spectrum. We consider only the three highest levels as genuine engagement and use the term public participation to refer to all levels of participation and public engagement to refer to only the three highest levels in this paper (Fig. 1).

\subsection{Engagement with adaptation}

Axon [20] (p. 84) distinguishes between passive and active engagement, where the latter means "what is done with the object of engagement" and the former implies "what is not done". This study views the concept of public engagement as a "personal state of connection" as defined by Lorenzoni et al. [21] (p.446) with climate change issues being recognized in cognitive, affective, and behavioural dimensions [20, 22-24]. Sutton and Tobin [23] (p.895) explain that: (1) the cognitive dimension (knowledge/understanding) relates to an individual's knowledge about climate change causes, impacts, and possible solutions; (2) the affective dimension (emotion/interest/concern) "relates to an individual's level of concern about climate change and its impacts"; and, (3) the behavioural dimension (action) involves actions that individuals may take to reduce the impacts of climate change.

In his study of public engagement in carbon reduction strategies Axon [20] identified various themes under each dimension of engagement. The cognitive dimension is underpinned by awareness and understandings, collective action and responsibility, sustaining interest to sustain participation, localising action, activating the link between awareness and participation, and other people's (non)participation. This dimension corresponds to public knowledge and awareness in our review. The affective dimension is concerned with positivity towards engagement and action, indifference and ambivalence, and negative responses and concern. The behavioural dimension includes willingness to become engaged, methods of participation, enablers of sustained engagement, and barriers to engagement. We review the literature examining evidence on the components of all these three dimensions.

\subsection{The policy cycle}

Althaus et al. [15] offer a policy cycle model of decision-making process that includes eight stages: issue identification, policy analysis, policy instruments, consultation, coordination, decision, implementation, and evaluation (Fig. 1). While the fourth stage of the policy cycle explicitly includes a formal consultation process, public engagement should be incorporated into all other stages from the identification of issues, through to policy evaluation for better outcomes. Mabelis and Maksymiuk [25] (p. 73) note that: "the basic idea of community engagement/public participation is to include all stakeholders in the planning process, from start (defining the aims) to end (providing a plan and monitoring its implementation)". There are significant benefits to public participation and engagement such as community development and empowerment that can occur through a high level of public engagement.

The third stage of the policy cycle involves choosing the appropriate kinds of policy instruments. These include advocacy, networks, money, government action, law, behavioural economics, and narrative [15]. Public engagement can help in selecting the most appropriate policy instruments and society can in turn be influenced by these instruments. The relationship between public engagement and the policy instruments is two-way, which is very important in climate adaptation. For instance, advocacy in the form of information sharing can be used as a policy instrument to improve public motivation through information flows and accountability. Communities' expectations and behaviours can also influence advocacy $[26,27]$. The media has a key role to play in the deployment of this instrument.

Another important policy instrument is networking. A study by Bahauddin et al. [10] shows that strong relationships and collaboration between government and different communities are important in the climate change adaptation process. Networking can improve the relationship between governments and citizens. It can also provide a shared vision that encourages individuals and communities to engage with the climate change adaptation process. Other policy instruments, such as money, law, and behavioural economics can influence community actions regarding climate change 


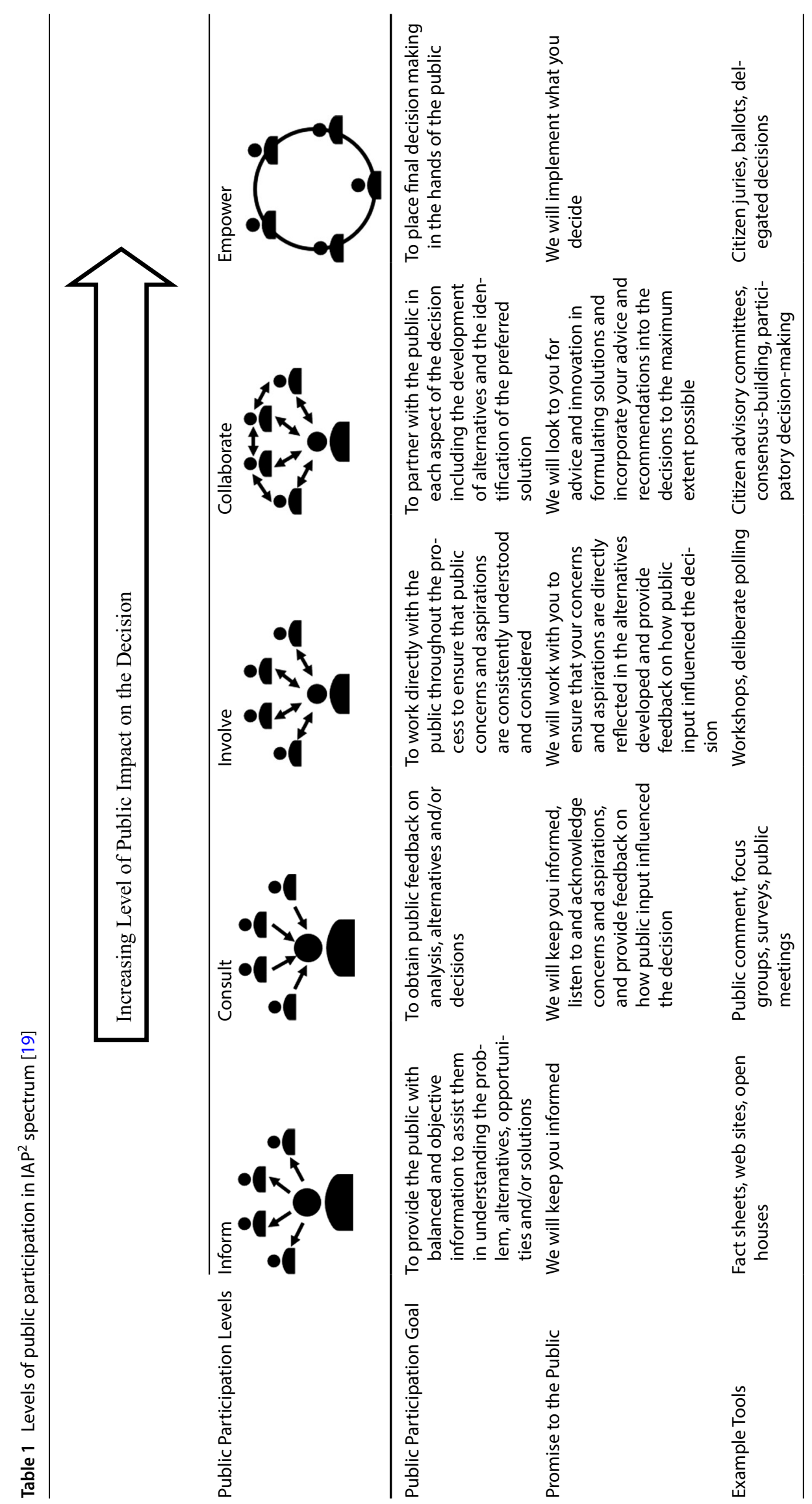


adaptation and can help to build resilience. Narrative as a policy instrument can provide a vision and context for debate that engages the stakeholders [15].

\subsection{Types of knowledge}

Public engagement is the key to improving the decision-making process during climate change adaptation [11]; however, appropriate public knowledge and awareness are important in creating public support for climate policies and plans $[4,10,14]$. The results of a study related to volunteer environmental monitoring indicate how increased personal knowledge and community awareness influence changing attitudes and behaviours and promote changes in natural resource management and related policies [28].

There are various forms of knowledge such as individual, local, traditional, indigenous, and scientific, that are important in decision-making. Semali and Kincheloe [29] describe local knowledge systems as the systematic information that remains in the informal sector, is usually unwritten, and is preserved in oral traditions rather than texts. It is created by local people who integrate new technologies into their knowledge system. Olsson and Folke [30] believe that local knowledge is a combination of scientific and practical knowledge which involves a belief system and differs from traditional ecological knowledge. Traditional or indigenous knowledge systems include knowledge of ecosystem relationships with a code of ethics guiding the use of the environment [31,32]. This code incorporates rules and conventions elevating desirable ecosystem relations with social relationships and human-nature interactions [31].

The distinction between local or traditional knowledge and scientific knowledge is important [32-35]. Recognizing the contexts in which each way of knowing occurs is key to utilizing knowledge effectively [35]. In order to acknowledge climate change risks, take responsibility, and address the relevant issues, it is necessary to have a process which uses local and traditional knowledge, values, and scientific information simultaneously to create a legitimate understanding [36]. This kind of understanding would strengthen the relationships between the public, experts, and governments during climate risks and enable consideration of potent related policies.

Research suggests that scientific information needs to be perceived by stakeholders to be credible, salient, and legitimate [37], as well as useful and usable [38] to influence policy. Cash et al. [37] suggest that the perceived salience, credibility, and legitimacy of knowledge is increased by active, iterative, and inclusive communication; mutual understanding through translation of knowledge to appropriate language; and resolution of conflicts through improved understanding and mediation. These benefits can be achieved by well-crafted public engagement processes. Lemos and Morehouse [38] view the interaction between stakeholder participation and the production of knowledge as critical in making that knowledge useful and usable.

\section{Methods}

Systematic reviews are proliferating as the volume of scientific research expands. There are several advantages of systematic methods including the minimisation of potential biases that may arise in some narrative style reviews [39-41]; however, if they are not conducted with the same level of rigour as primary research they may also contain bias [42]. Solely identifying articles through a systematic search does not make a review systematic. As Haddaway and Bilotta [43] (p.579) note "a systematic review normally involves a number of purposeful formalised stages" that include: (1) developing a protocol; (2) searching across multiple sources of evidence; (3) screening evidence for relevance; (4) retrieving articles; (5) critically appraising study validity; (6) extracting data; (7) performing synthesis of qualitative and/ or quantitative data; and (8) documenting all activities in a detailed report [42] (p. 444). These strict methodological steps are essential to avoid the pitfalls of systematic reviews including: a lack of transparency, comprehensiveness, and consistency; bias in selection, media attention, citation, database, publication, place of publication, language, interpretation, dissemination, reporting, and time lag; and subject drift [43,44]. Reporting standards are a way of ensuring sufficient methodological detail is provided to allow for verification and replication [42].

The systematic quantitative literature review presented here follows the method outlined by Pickering and Byrne [45]. This method has been widely used for research on topics ranging from ecological restoration [46], to sustainability [47], parks provision [48], and adaptation to sea level rise [49]. The literature search was conducted using Scopus, ScienceDirect, and Google Scholar electronic databases in March 2017 and updated in August 2020. A search string was developed by including a combination of the keywords: (public OR stakeholder OR citizen OR civic OR 
community) AND (awareness OR knowledge OR recognition OR understanding) AND (participation OR engagement OR involvement) AND "climate change". The search was limited to English language publications and no time limitation was set.

These searches resulted in over ten thousand records. For searches that returned more than thousand records the records were scanned until no new relevant items turned up on a page. The protocols of the Preferred Reporting Items for Systematic Reviews and Meta-Analyses (PRISMA) statement [50] were used to develop a PRISMA diagram (see Fig. 2). After omitting duplicates, the remaining records $(n=3539)$ were screened by the inclusion criteria of document type (peer reviewed journal articles) and focus of the article based on the research question. The peer-reviewed articles were then screened by reading the abstracts and those that were deemed not relevant were excluded. Additional articles were identified through backward and forward reference searching of the identified articles.

The remaining records $(n=235)$ were read fully and a further 157 papers were excluded based on relevance to the research question. A final set of 78 papers were selected to be included in the systematic review and are noted with an asterisk in the references. All relevant variables were identified and the papers were reviewed by recording the information in an Excel database based on the analytical framework outlined in the Appendix (Table 7). The framework includes information on the article and the journal, case study locations, research design and methods, and the three main elements of the study: the dimensions, level, focus, and timing of public participation and its barriers; public awareness and types of knowledge; and policy instruments.

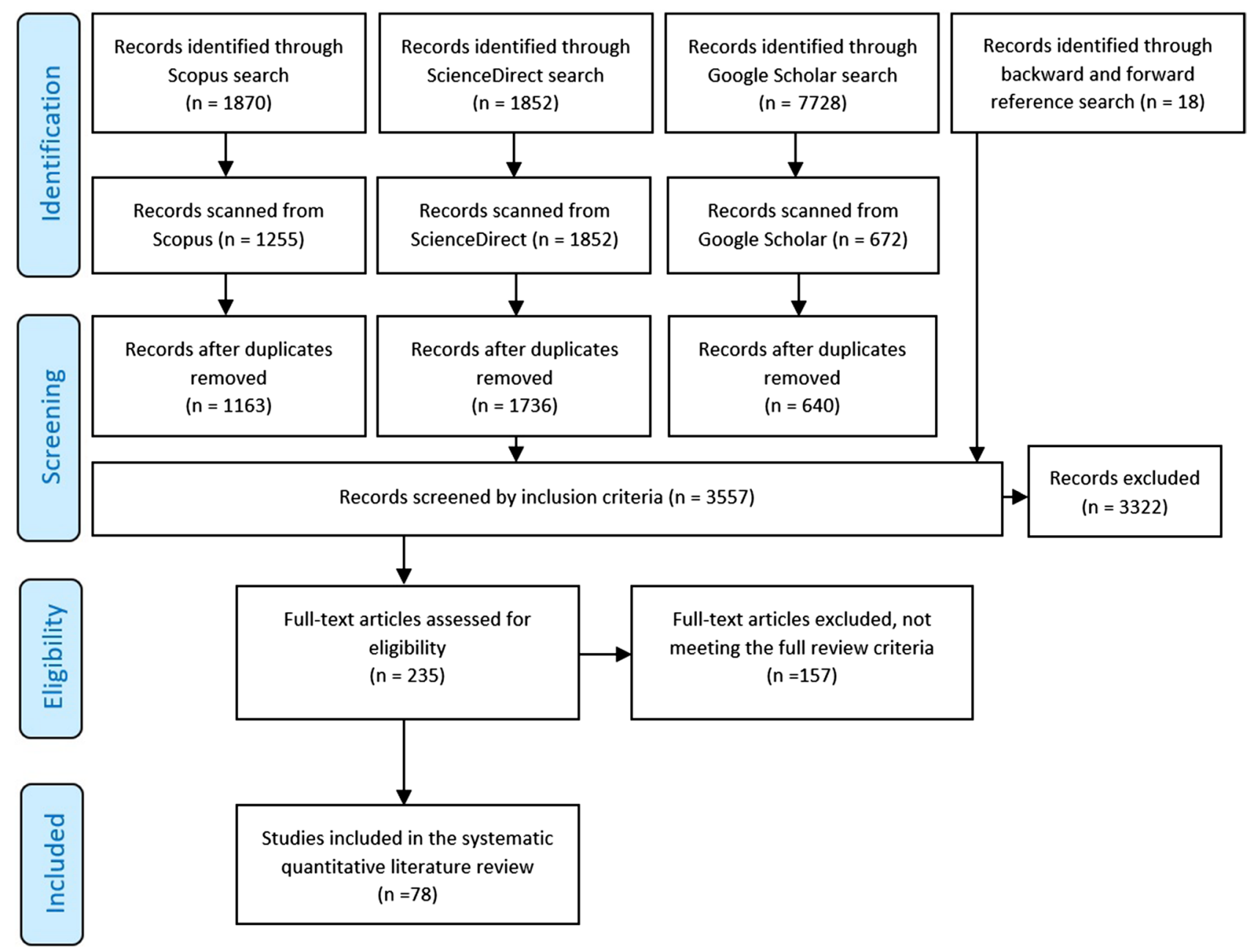

Fig. 2 PRISMA Flow Diagram for the SQLR 


\section{Results}

The amount of research on climate adaptation that includes public awareness, knowledge, and engagement has substantially increased in recent years (Appendix, Table 8). The SQLR analysis indicates that $47 \%$ of the articles explored climate change adaptation and $17 \%$ were focused on climate change mitigation. Around $23 \%$ focused on both adaptation and mitigation, while $13 \%$ of the papers focused on climate change in general.

\subsection{Overview of the articles}

The 78 articles included in the study were published in 55 different journals within 18 disciplines (Appendix, Table 8). Environmental studies journals contained the largest number of these articles (45\%) followed by meteorology (9\%), earth science (8\%), and housing and urban planning (6\%). Forests and forestry and social sciences published $5 \%$ of the articles each and geography and sociology followed with $4 \%$ each. Only $3 \%$ of the articles were published in psychology and the remainder were published in a variety of disciplines.

The oldest paper in the review dated back to 1999 , however, most of the articles (77\%) were published in the past eight years. Figure 3 shows a dramatic increase in the volume of scholarly research on this topic in the last decade peaking in 2013 with 13 articles. While the review itself does not provide a reason for this peak, a major contributing factor may have been the unusual series of destructive climate-related disasters around the world in 2012 (see, for example, [51]) combined with the release of an IPCC special report on extreme weather events and their link to climate change [52]. Another factor may have been the United Nations Conference on Sustainable Development (Rio + 20) in 2012 that included considerable international debate about climate change.

The location of the case studies and first authors of the articles indicate that the research on public awareness, knowledge, participation, and climate change mostly originates from and focuses on developed nations (Table 2). The most number of case studies on this topic are located in Europe (38\%) (such as Pietrapertosa et al.'s [53] survey of 11 South East European countries), North America (17\%) (including [11, 54, 55]), Asia (15\%) (e.g. [2, 56-59]) and Australia (12\%) (e.g. [60-62]). The rest were spread across Africa (6\%), Oceania (4\%) and South America (3\%). Approximately $17 \%$ of the papers covered a large number of international case studies. A good example is Amaru and Chhetri's [63] study of 45 cases of adaptation that examined the roles of institutions and other stakeholders in innovation in climate adaptation. Likewise, Figueiredo and Perkins' [64] research on two international projects (the Sister Watersheds project involving Brazil and Canada and a Climate Change Adaptation in Africa project involving Canada, Kenya, Mozambique, and South Africa) revealed that engaging women is important as they possess unique local ecological knowledge on water management.

More than $50 \%$ of the case studies are in developed countries. The UK has been the most popular case study location with 14 publications followed by Australia (9), US (8) and Canada (4). Although developing countries were studied less frequently compared to developed countries, some developing countries from Asia such as Bangladesh, Nepal, and India were examined more than some developed countries such as Austria, Spain, and Belgium reflecting their high level of vulnerability to climate change impacts.

As expected, the locations of the first authors of the studies closely parallel the region where the research was undertaken, with Europe leading again (44\%). North America (28\%) and Oceania (21\%) produced a significant amount of the research, whereas Asia (5\%) and Africa (3\%) are underrepresented.

Fig. 3 Volume of scholarly articles on public awareness, knowledge, and engagement in climate response (2020 figures go up to August only)

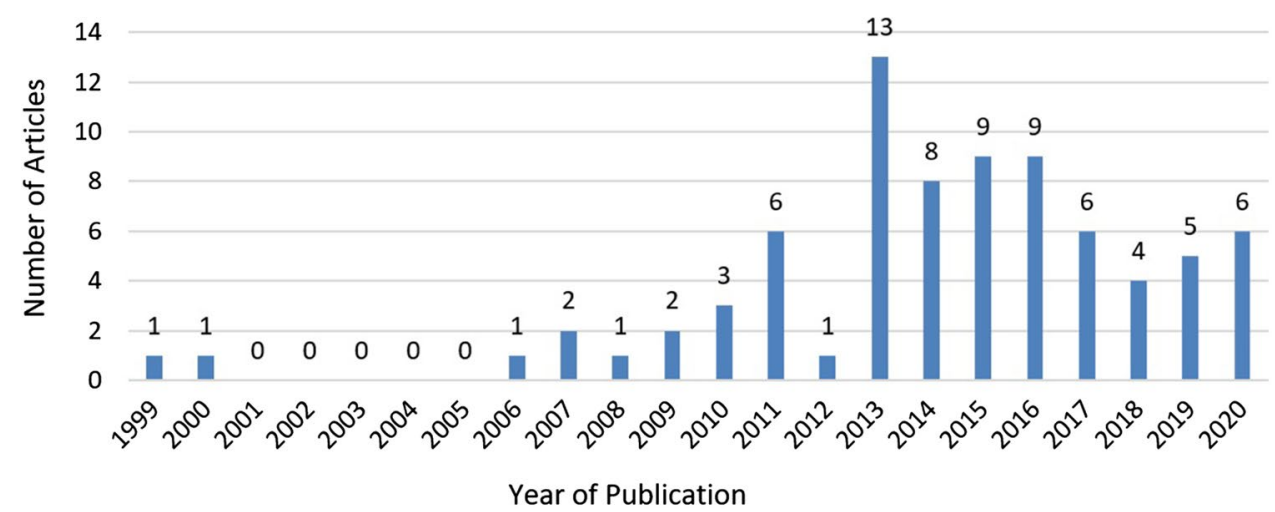


Table 2 Location of the case studies

\begin{tabular}{|c|c|c|c|c|c|}
\hline Location & $\begin{array}{l}\text { Single case } \\
\text { studies }\end{array}$ & Two cases & $\begin{array}{l}\text { Three-four } \\
\text { cases }\end{array}$ & $\begin{array}{l}\text { Wide scope } \\
\text { articles }^{\mathrm{a}}\end{array}$ & $\begin{array}{l}\text { Frequency } \\
\text { of studies }\end{array}$ \\
\hline International & & & & 13 & 13 \\
\hline UK & 14 & 1 & & & 15 \\
\hline Australia & 9 & & & & 9 \\
\hline US & 8 & & & & 8 \\
\hline Canada & 4 & & 1 & & 5 \\
\hline Bangladesh & 3 & & & & 3 \\
\hline Austria & & & 1 & & 1 \\
\hline Germany & & 1 & 1 & & 2 \\
\hline Spain & & & 1 & & 1 \\
\hline Portugal & 3 & & & & 3 \\
\hline China & 1 & & & & 1 \\
\hline Belgium & 2 & & & & 2 \\
\hline Nepal & 2 & & & & 2 \\
\hline Sweden & 3 & & & & 3 \\
\hline Finland & 1 & & & & 1 \\
\hline Ecuador & & 1 & & & 1 \\
\hline India & 1 & 1 & 1 & & 3 \\
\hline South Africa & 3 & & & & 3 \\
\hline Kenya & & & 1 & & 1 \\
\hline Burkina Faso & & & 1 & & 1 \\
\hline Brazil & & & 1 & & 1 \\
\hline Netherlands & 3 & & & & 3 \\
\hline Indonesia & 1 & & & & 1 \\
\hline Taiwan & 1 & & & & 1 \\
\hline Vietnam & 1 & & & & 1 \\
\hline Oceania Islands & & & 1 & & 1 \\
\hline Number of articles & 60 & 2 & 3 & 13 & NA \\
\hline Percentage $(n=78)$ & $77 \%$ & $3 \%$ & $4 \%$ & $17 \%$ & NA \\
\hline
\end{tabular}

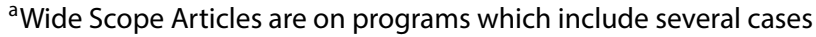

\subsection{Research design and methods}

A range of different research designs were used in the reviewed articles, the most popular being exploratory (27\%), case studies (26\%), and cross-sectional studies (23\%). Other research designs included comparative and descriptive analysis (6\% each), longitudinal studies (4\%), historical and mixed method studies ( $3 \%$ each), and experimental and observation studies (1\% each). More than half of the studies used interviews for data collection. Chu et al. [56], for example, interviewed members of various institutions regarding how civil society engaged in different stages of climate change adaptation planning and implementation. Other data collection methods used in the literature reviewed included surveys $(37 \%)$, focus groups (29\%), field research $(28 \%)$, observation $(26 \%)$, and the compilation of archival records and documents (24\%). Most of the studies used qualitative data analysis methods $(50 \%)$, followed by mixed methods (including a combination of qualitative and quantitative methods) (23\%) and quantitative methods (22\%). Spatial analysis was used in very few studies (5\%) such as Cloutier et al. [65], Sheppard et al. [66], and Groot et al. [67] (Fig. 4).

\subsection{Awareness and knowledge of climate change}

The review results illustrate the importance of the link between public awareness and different types of knowledge of climate change, with $72 \%$ of studies making the connection (for example, $[4,20,66]$ ) (Table 3 ). Most of the studies 
Fig. 4 Research design and methods

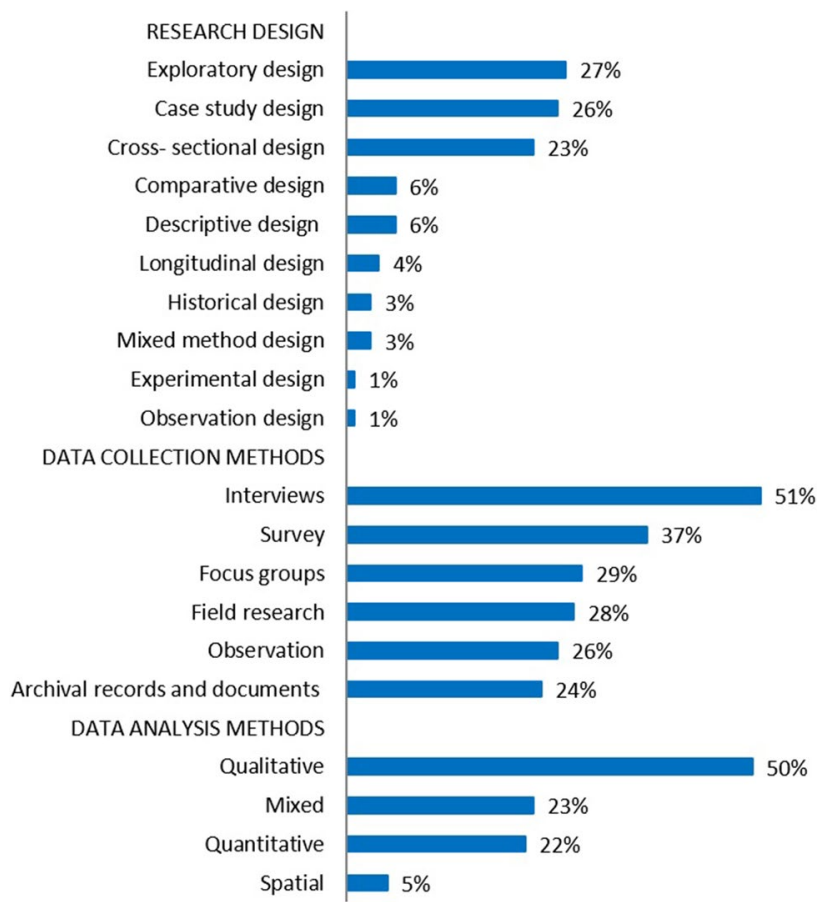

Table 3 Importance of awareness and type of knowledge

\begin{tabular}{|c|c|c|c|c|c|}
\hline Awareness and type of knowledge & $\begin{array}{l}\text { Adaptation focus } \\
\text { Number (\%) }\end{array}$ & $\begin{array}{l}\text { Mitigation focus } \\
\text { Number (\%) }\end{array}$ & $\begin{array}{l}\text { Both } \\
\text { Number (\%) }\end{array}$ & $\begin{array}{l}\text { General } \\
\text { Number (\%) }\end{array}$ & $\begin{array}{l}\text { Total } \\
\text { Number (\%) }\end{array}$ \\
\hline Importance of awareness & $29(37 \%)$ & $10(13 \%)$ & $10(13 \%)$ & $7(9 \%)$ & $56(72 \%)$ \\
\hline Individual knowledge & $30(38 \%)$ & $11(14 \%)$ & $14(18 \%)$ & $8(10 \%)$ & $63(81 \%)$ \\
\hline Scientific knowledge & $30(38 \%)$ & $7(9 \%)$ & $14(18 \%)$ & $9(12 \%)$ & $60(77 \%)$ \\
\hline Local knowledge & $27(35 \%)$ & $5(6 \%)$ & $16(21 \%)$ & $5(6 \%)$ & $53(68 \%)$ \\
\hline Traditional knowledge & $11(14 \%)$ & $2(3 \%)$ & $9(12 \%)$ & $2(3 \%)$ & $24(31 \%)$ \\
\hline Total articles & 37 (47\%) & 13 (17\%) & 18 (23\%) & 10 (13\%) & 78 (100\%) \\
\hline
\end{tabular}

(81\%) focused on individual knowledge rather than other types of knowledge. Wolf and Moser [24] and Luís et al. [68], for example, point out that individual knowledge can be effective in responding to climate risks.

Nearly $77 \%$ of the articles highlighted the importance of scientific knowledge and its understanding for improving stakeholders' engagement including Chilvers et al. [69] and Vulturius and Gerger Swartling [70]. Pasquier et al. [71] focused on the integration of stakeholder and scientific knowledge in assessing flood risk and identifying adaptation measures. Local knowledge was covered in $68 \%$ of the papers. For example, a study of climate change adaptation strategies in three forest-dependent indigenous communities in Bangladesh by Rahman and Alam [72] showed the importance of local knowledge in providing fair mechanisms for local communities to take climate adaptation action. In addition, there are several positive stories of community-based climate change adaptation projects in the Pacific region, where communities engaged actively in the project development and implementation process, enabling the integration of local knowledge [73]. However, based on their study in Vietnam, Bruun and Olwig [74] warn that the available local knowledge is anthropocentric and opportunistic, so while it may help communities cope with impacts of climate change and disasters, it contributes little towards overall "resilience" and "equilibrium". They argue that it may actually exacerbate risk in the long term.

The results also indicate that traditional knowledge is more important in adaptation than mitigation. One third of the articles specified the importance of traditional knowledge in climate change (see for example, [72, 75]). In their study of the East Kimberly region of Australia, Leonard et al. [61] (p. 631) demonstrate the importance of traditional ecological knowledge and how it "can contribute towards improved understandings about the impacts of climate change and provide insight for the development of equitable and effective climate change adaptation strategies". 


\subsection{Engagement in climate change}

Of the three dimensions of active engagement (i.e. cognitive, affective, and behavioural), cognitive is mentioned most often in the literature reviewed (Table 4). Two components of the cognitive dimension, increasing knowledge and changing attitude and the strong link between awareness and participation are reported in 80 and $76 \%$ of the papers respectively. Madumere [4], for example, argues that enhancing public awareness and participation, and their interaction, was key in addressing climate change impacts. Another cognitive aspect, learning new skills, appears in $33 \%$ of the papers. Vulturius and Gerger Swartling [70] (p. 220) show "how the focus group discussions provided participants with the opportunity for both instrumental (fact-and skill-focused) learning and communicative learning (understanding one's own and others' perspectives)". Improvement of social learning skills or learning ability of communities through engagement was mentioned, for example, by Burnside-Lawry and Carvalho [76] who show how changes in knowledge and understanding of the participants were reflected in modified policies and practice by both decision-makers and stakeholders and subsequently how the level of community resilience is increased through active public engagement. Among affective components of active engagement, $62 \%$ of papers mention positivity (attitude) in engagement and action. From the behavioural components of active engagement in climate change, willingness to engage was discussed in $54 \%$ of the papers in relation to positive experiences of involvement and changing behaviour positively in nearly half of the articles (47\%), including studies by Axon [20], Burton and Mustelin [3], Madumere [4], Sheppard et al. [66], Whitmarsh et al. [77], Wolf and Moser [24], and Luís et al. [68].

Of the two dimensions of passive engagement (cognitive and affective), $50 \%$ of the articles refer to lack of knowledge and awareness as an important cognitive component (e.g. [67, 78-81]). Nunn et al. [82] identified the lack of knowledge and awareness as an important barrier to active public engagement among key community decision makers in climatechange adaptation. To address the issue, Thaker et al. [59] suggest that mass media and targeted campaigns could play an important role by educating citizens about climate change issues, instead of reporting climate change in the context of natural disasters. Only $22 \%$ of the papers mentioned negative response and concern as one of the affective components of passive engagement.

The reviewed articles indicate that there is a link between active engagement and the level of awareness of climate change. Increasing knowledge of climate risks and attitude changes can occur through active engagement which can in turn positively impact the behavioural dimension (e.g. people's willingness to engage). In addition, the lack of knowledge and awareness about climate change are important factors that need to be considered.

Table 4 Dimensions of engagement in climate change

\begin{tabular}{|c|c|c|c|c|c|}
\hline Dimension of engagement & $\begin{array}{l}\text { Adaptation } \\
\text { Number (\%) }\end{array}$ & $\begin{array}{l}\text { Mitigation } \\
\text { Number (\%) }\end{array}$ & $\begin{array}{l}\text { Both } \\
\text { Number (\%) }\end{array}$ & $\begin{array}{l}\text { General } \\
\text { Number (\%) }\end{array}$ & $\begin{array}{l}\text { Total } \\
\text { Number (\%) }\end{array}$ \\
\hline \multicolumn{6}{|l|}{ Active } \\
\hline \multicolumn{6}{|l|}{ Cognitive } \\
\hline Increasing knowledge and changing attitude & $30(38 \%)$ & $12(15 \%)$ & $14(18 \%)$ & $7(9 \%)$ & $63(80 \%)$ \\
\hline Strong link between awareness and participation & $26(33 \%)$ & $13(17 \%)$ & $15(19 \%)$ & $5(6 \%)$ & $59(76 \%)$ \\
\hline Learning new skills & $15(19 \%)$ & $2(3 \%)$ & $6(8 \%)$ & $3(4 \%)$ & $26(33 \%)$ \\
\hline \multicolumn{6}{|l|}{ Affective } \\
\hline Positivity in engagement and action & $19(24 \%)$ & $10(13 \%)$ & $12(15 \%)$ & $6(8 \%)$ & $48(62 \%)$ \\
\hline \multicolumn{6}{|l|}{ Behavioural } \\
\hline Willing to engage & $21(27 \%)$ & $7(9 \%)$ & $8(10 \%)$ & $6(8 \%)$ & $42(54 \%)$ \\
\hline Positive behavioural change & $12(15 \%)$ & $7(9 \%)$ & $13(17 \%)$ & $5(6 \%)$ & $37(47 \%)$ \\
\hline \multicolumn{6}{|l|}{ Passive } \\
\hline \multicolumn{6}{|l|}{ Cognitive } \\
\hline Lack of knowledge and awareness & $16(21 \%)$ & $11(14 \%)$ & $7(9 \%)$ & $5(6 \%)$ & $39(50 \%)$ \\
\hline \multicolumn{6}{|l|}{ Affective } \\
\hline Limited emotional connection and lack of interest & $9(12 \%)$ & $8(10 \%)$ & $11(14 \%)$ & $2(3 \%)$ & $30(38 \%)$ \\
\hline Negative responses and concern & $2(3 \%)$ & $7(9 \%)$ & $6(8 \%)$ & $2(3 \%)$ & $17(22 \%)$ \\
\hline Total articles & $37(47 \%)$ & $13(17 \%)$ & $18(23 \%)$ & $10(13 \%)$ & $78(100 \%)$ \\
\hline
\end{tabular}




\subsection{Level and timing of public participation in climate change}

Among the five levels of public participation defined by the IAP [19], the reviewed literature reports the lowest three levels of public participation (inform, consult, and involve) much more frequently than the two higher levels (collaborate and empower) (Table 5). Moreover, the review shows that public participation was occurring more during policy development and decision-making stages of the policy cycle than implementation or evaluation.

The most frequently reported levels of participation in the literature are inform and involve (each mentioned in $92 \%$ of the articles). Informing the public is the lowest level of public participation and many studies point out that this usually occurs without feedback to the public (see $[5,10,83,84]$ for examples). However, this gap can easily be addressed by mass media. Thaker et al. [59] (p. 681) show that mass media plays a vital role in increasing the collective efficacy ("people's shared beliefs about their group's capabilities to accomplish collective tasks") perceptions of the public by supplying authentic sources of information and updates. In other words, media can be a mediator assisting in public participation. Involving the public occurs usually during policy development (from identifying issues to consultation) (79\%), decision-making (60\%), and implementation phases (55\%). Studies such as Pietrapertosa et al's [53] show how policy development can occur with active public engagement when a community is experiencing the impacts of climate change.

The highest level of public participation, empowering the public, was only mentioned in $9 \%$ of the articles. Studies by Nunn et al. [82] and Wiseman et al. [60], for example, emphasise the direct link between the empowerment of communities with their motivation to take action on climate change. In their evaluation of the performance of 18 adaptation projects by the Global Environment Facility, Sherman and Ford [85] found a greater emphasis on

Table 5 Level and timing of public participation in climate change

\begin{tabular}{|c|c|c|c|c|c|c|}
\hline Level and timing of public participation & $\begin{array}{l}\text { Adaptation } \\
\text { Number (\%) }\end{array}$ & $\begin{array}{l}\text { Mitigation } \\
\text { Number (\%) }\end{array}$ & $\begin{array}{l}\text { Both } \\
\text { Number (\%) }\end{array}$ & $\begin{array}{l}\text { General } \\
\text { Number (\%) }\end{array}$ & $\begin{array}{l}\text { Phase total } \\
\text { Number (\%) }\end{array}$ & $\begin{array}{l}\text { Level total } \\
\text { Number (\%) }\end{array}$ \\
\hline Inform & & & & & & $72(92 \%)$ \\
\hline Policy development & $33(42 \%)$ & $11(14 \%)$ & $16(21 \%)$ & $9(12 \%)$ & $69(88 \%)$ & \\
\hline Decision-making & $17(22 \%)$ & $7(9 \%)$ & $7(9 \%)$ & $5(6 \%)$ & $36(46 \%)$ & \\
\hline Implementation & $11(14 \%)$ & $2(3 \%)$ & $5(6 \%)$ & $2(3 \%)$ & $20(26 \%)$ & \\
\hline Monitoring and Assessment & $6(8 \%)$ & $2(3 \%)$ & $3(4 \%)$ & $1(1 \%)$ & $12(15 \%)$ & \\
\hline Consult & & & & & & $26(33 \%)$ \\
\hline Policy development & $16(21 \%)$ & $3(4 \%)$ & $2(3 \%)$ & $3(4 \%)$ & $24(31 \%)$ & \\
\hline Decision-making & $9(12 \%)$ & $3(4 \%)$ & $1(1 \%)$ & $2(3 \%)$ & $15(19 \%)$ & \\
\hline Implementation & $3(4 \%)$ & $2(3 \%)$ & $1(1 \%)$ & $1(1 \%)$ & $7(9 \%)$ & \\
\hline Monitoring and assessment & $1(1 \%)$ & $2(3 \%)$ & $0(0 \%)$ & $0(0 \%)$ & $3(4 \%)$ & \\
\hline Involve & & & & & & $72(92 \%)$ \\
\hline Policy development & $29(37 \%)$ & $10(13 \%)$ & $18(23 \%)$ & $5(6 \%)$ & $62(79 \%)$ & \\
\hline Decision-making & $24(31 \%)$ & $8(10 \%)$ & $10(13 \%)$ & $5(6 \%)$ & $47(60 \%)$ & \\
\hline Implementation & $22(28 \%)$ & $5(6 \%)$ & $11(14 \%)$ & $5(6 \%)$ & $43(55 \%)$ & \\
\hline Monitoring and Assessment & $7(9 \%)$ & $0(0 \%)$ & $3(4 \%)$ & $3(4 \%)$ & $13(17 \%)$ & \\
\hline Collaborate & & & & & & $22(28 \%)$ \\
\hline Policy development & $16(21 \%)$ & $0(0 \%)$ & $4(5 \%)$ & $0(0 \%)$ & $20(26 \%)$ & \\
\hline Decision-making & $8(10 \%)$ & $0(0 \%)$ & $1(1 \%)$ & $2(3 \%)$ & $11(14 \%)$ & \\
\hline Implementation & $6(8 \%)$ & $0(0 \%)$ & $3(4 \%)$ & $1(1 \%)$ & $10(13 \%)$ & \\
\hline Monitoring and Assessment & $1(1 \%)$ & $0(0 \%)$ & $1(1 \%)$ & $1(1 \%)$ & $3(4 \%)$ & \\
\hline Empower & & & & & & $7(9 \%)$ \\
\hline Policy development & $3(4 \%)$ & $0(0 \%)$ & $1(1 \%)$ & $0(0 \%)$ & $4(5 \%)$ & \\
\hline Decision-making & $3(4 \%)$ & $0(0 \%)$ & $1(1 \%)$ & $0(0 \%)$ & $4(5 \%)$ & \\
\hline Implementation & $2(3 \%)$ & $0(0 \%)$ & $2(3 \%)$ & $0(0 \%)$ & $4(5 \%)$ & \\
\hline Monitoring and assessment & $1(1 \%)$ & $0(0 \%)$ & $0(0 \%)$ & $0(0 \%)$ & $1(1 \%)$ & \\
\hline Total number of articles & 37 (47\%) & $13(17 \%)$ & $18(23 \%)$ & $10(13 \%)$ & 78 & \\
\hline
\end{tabular}


community empowerment in bottom-up approaches compared to top-down approaches but warned that if the engagement strategy is not designed properly it will not result in capacity building and empowerment.

Most of the studies reviewed conclude that higher levels of participation generally produce better outcomes. For example, Chu et al's [56] study on how civil society actors contribute to adaptation planning and implementation in Ecuador and India found that more inclusive decision-making, implementation of climate actions, and monitoring in the planning processes resulted in more equitable and just outcomes in the short term. Burnside-Lawry and Carvalho's [76] (p. 4) examination of stakeholder engagement activities that increase risk awareness and encourage collective action for a local government in Portugal indicated that "the implementation of a wide spectrum of public engagement initiatives" including activities in schools, child-care centres, aged-care facilities, homes for the disabled had "improved community and government capacity to identify and implement risk reduction strategies". Serrao-Neumann et al.'s [5] analysis of three local government led public participation initiatives in Australia using the IAP ${ }^{2}$ framework for public participation found that higher levels of participation such as collaboration can provide scope for deliberation of critical issues, transparency in decision making, and potential to build community capacity and social capital. Another study examining civic capacity in urban governance of climate change adaptation across multiple cases from around the world similarly found that civic capacity existed when participation took the forms of involvement or higher on the IAP ${ }^{2}$ spectrum [83].

\subsection{Barriers to public participation in climate change}

Expanding on Arnstein's [18] limitations for public participation Sprain [86] identified barriers for organizations and communities as well as for governance of sustained participation in climate change governance. Among barriers for organisations and communities the reviewed literature reported lack of motivation (44\%) and resistance to power redistribution (40\%) most frequently, followed by paternalism (38\%) and bias (29\%) (Table 6).

Three studies specifically focused on barriers to engagement in climate change. Lorenzoni et al. [21] identify barriers that operate at individual and social levels and call for targeted and tailored information provision. Jeffers [87] argues for a wider change in hazard management policy and resourcing for more effective public participation in hazard management and climate change adaptation. Wamsler et al. [81] suggest that under current structures and mechanisms, public engagement hinders sustainable outcomes and call for explicit support and systematic mainstreaming of public engagement to support sustainability. They identify lack of cognitive capacity, current power structures, and lack of interest and motivation of citizens as key barriers. Studies by Scannell and Gifford [88] and Thaker et al. [59] suggest that motivation plays an important role in public engagement.

Among barriers related with the governance of sustained participation, inadequate political socioeconomic infrastructure of the poor communities and knowledge base (72\%) was identified by most of the articles. Sethamo et al's [80] case study in Botswana asked the participants about their knowledge on climate change and received mostly vague and brief responses which clearly demonstrated the respondents' lack of knowledge. Wamsler et al. [81] identified a lack of proper mechanism for monitoring and learning process in place which adversely impacted public participation.

Another important barrier for governance of sustained participation was the difficulties of organizing a representative and accountable citizens' group in the face of futility, alienation, and distrust (40\%). Hügel and Davies' [89] recent review found that lack of trust affects citizens' willingness to get involved in climate change adaptation. Lack of trust could stem from different factors such as experiencing unsuccessful public participation trials by major governance bodies [87]. The formation of distrust could immediately result in lack of citizens' willingness for future engagement. The remaining barriers for governance of sustained participation are all mentioned in less than half of the papers (Table 6).

Research into the UK's community-based carbon reduction strategies found that higher levels of citizen participation in the IAP ${ }^{2}$ spectrum (involve, collaborate, and empower-which we view as forms of genuine engagement) are essential for sustained participation in community initiatives [20]. Several studies highlight how higher levels of participation activities can help overcome some of the barriers to sustained participation such as lack of knowledge, trust, and motivation. Collaborative social learning occurs through the interactions between participants during engagement events and this learning "enables changes in knowledge and understanding that are reflected in modified policies and practice by decision-makers and stakeholders" [76] (p. 7). While case studies of Portuguese coastal communities concluded creative participatory learning processes can help build trust which in turn can improve participation [90] studies of rural coastal communities in Michigan, United States revealed the need for multiple engagement opportunities and community-building techniques involving social learning to progress climate change planning initiatives to adoption and implementation [91]. Larsen and Gunnarsson-Östling [92] found that engaging citizens in visionary activities such as constructing climate change scenarios builds trust through exchange of ideas, learning, and mutual understanding. 


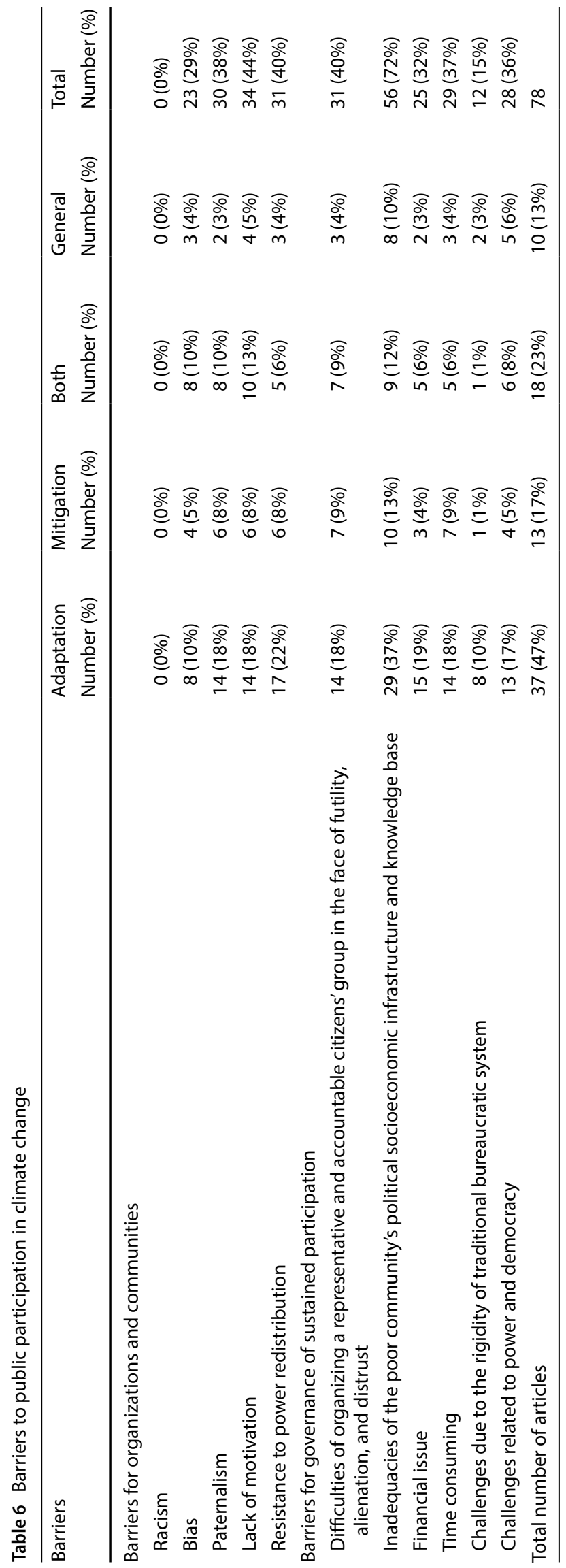


Stepenuck and Green's [28] review of the literature on volunteer environmental monitoring identified increased individual knowledge, engagement, and environmental stewardship and improved social capital and trust among all stakeholders as outcomes of participation.

\subsection{Policy instruments used in climate change action}

From the list of policy instruments Althaus et al. [15] describe overall advocacy (87\%) and networking (81\%) are mentioned more often in climate change action than other types of policy instruments in the literature reviewed (Fig. 5). Advocacy in the form of information sharing and improved information flows and accountability is the single most mentioned policy instrument for climate change action (83\%). In order to increase public knowledge and understanding of climate change impacts and take effective action, information sharing was introduced as an important instrument in many cases. Information sharing about climate change can be achieved through mass media and reframing of issues can encourage public engagement [76,93]. Several studies suggest that the provision of basic information to communities and stakeholders, as well as information sharing between governments and stakeholders, are necessary to overcome the lack of knowledge related to climate change (e.g. $[2,4,21,60,63])$. Likewise, if barriers such as distrust in the sources of information are reduced, sharing information can improve engagement and climate action [21].

The next two most frequently reported policy instruments are two types of networking: (1) developing social capital, and (2) improving government-to-citizen relationship through new technologies. Putnam [94] (p. 664) defines social capital as: "features of social life networks, norms and trust that enable participants to act together more effectively to pursue shared objectives". Social capital development appears in $71 \%$ of the papers reviewed, indicating the importance of networking as a component of social capital in climate change action. Stepenuck and Green [28] and Wiseman et al. [60], for example, suggest that social capital can be increased by expanding personal networks in public engagement activities on climate action. To build social capital, knowledge sharing and facilitating information are essential [54, 62]. Improving government-citizen relationships through new technologies is reported in $60 \%$ of the papers. The results of the study by Bahauddin et al. [10], for example, suggest that strong relationships and collaboration between government and different communities are inevitable, particularly in the climate change adaptation process. This study shows the effectiveness of tools such as the Social Ecological Inventory (SEI) for resolving conflicts and building trust among stakeholders. (SEl is a tool used for participatory mapping to help participants identify ecological values and engage them

Fig. 5 Policy instruments used in climate change action

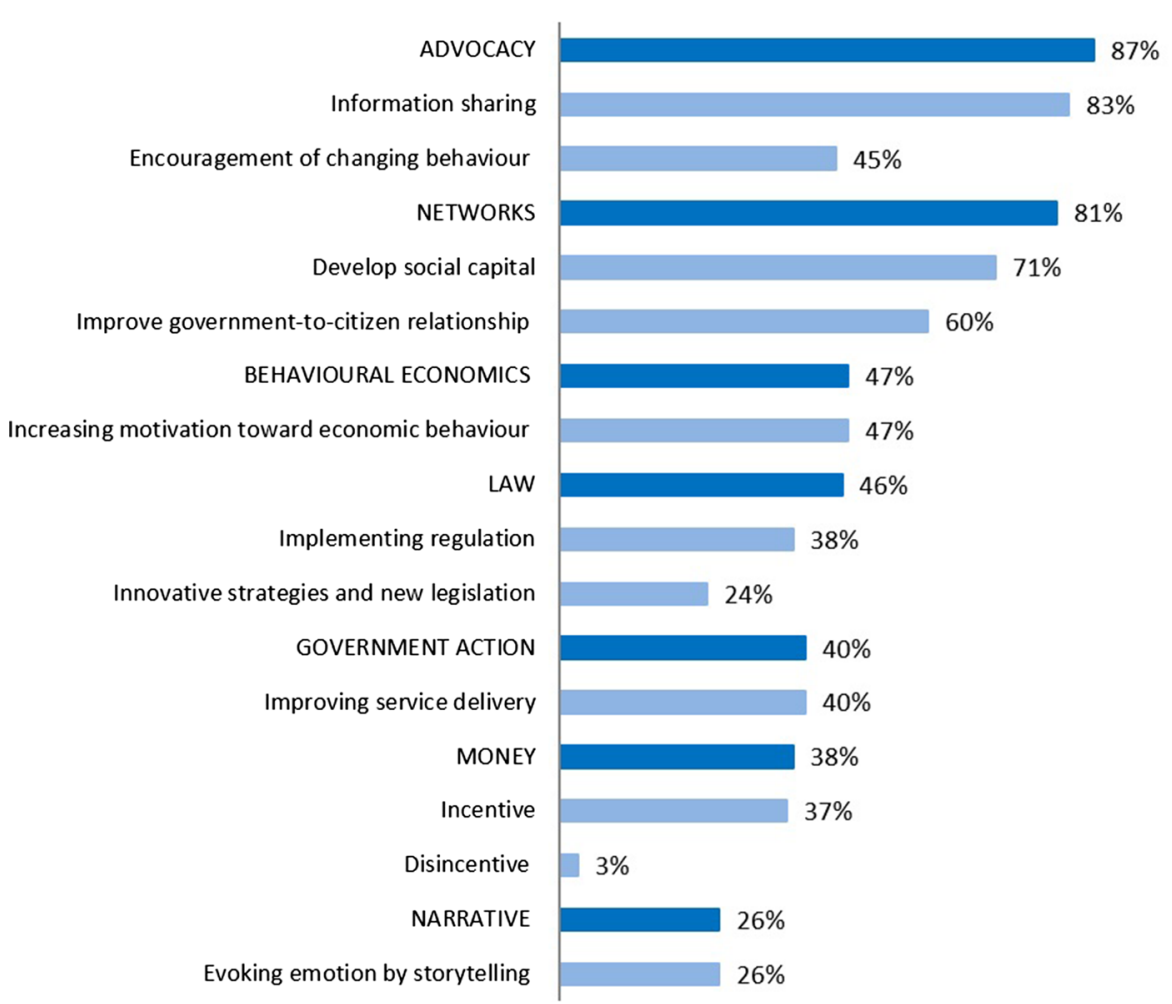


in all steps including monitoring, management, and learning process). Many sources of advanced local knowledge and gaps in scientific and/or local knowledge were identified in one regional coastal area of Bangladesh using the SEI tool.

Behavioural economics is the third highest reported policy instrument (47\%). Lorenzoni et al. [21] argue that changing people's lifestyle is an important climate change action, but public's lack of knowledge can be a barrier. The importance of economic benefits in motivating people to change their behaviour and take action on climate change is mentioned in various studies, including Axon's [20] work on carbon reduction, Lorenzoni et al.'s [21] research on the barriers to engagement in climate change in the UK, and Wiseman et al's [60] study on the effectiveness of public engagement strategies in improving climate mitigation and adaptation outcomes in Australia. For example, Lorenzoni et al. [21] explain how encouraging individuals through provision of information or economic incentives and subsidies can impact voluntary energy reduction. The rest of the policy instruments are all mentioned in less than half of the papers (Fig. 5).

\section{Discussion}

The focus of this review is to evaluate peer-reviewed studies to understand how public awareness, knowledge, and engagement can improve climate change adaptation policy. The implications of the findings for effective climate change adaptation are discussed in this section.

\subsection{Interaction of public awareness, knowledge, and engagement}

Overall, our findings point to a strong correlation between public awareness and knowledge and engagement in climate change action/policy (see $[57,62,69,76,93,95])$. The public's awareness and knowledge of climate change can contribute to their engagement in decision-making and increased engagement in turn can influence the community's level of awareness and knowledge. These findings are consistent with other research including Wibeck's [93] analysis of 92 peerreviewed studies of public understanding and communication on climate change which shows a positive relationship between knowledge and engagement. This research concludes that with regards to climate change action, although a lack of knowledge is an important barrier to active engagement, knowledge and awareness without engagement are not sufficient for changing people's behaviour and lifestyle. Moreover, the reviewed articles illustrate that public participation, and particularly active participation in environmental matters such as monitoring, can significantly contribute to gaining knowledge and awareness [28]. Together, public awareness, knowledge, and participation can drive changes in public behaviour and actions regarding climate change. Increased personal knowledge and community awareness of natural resource management issues, for example, can lead to attitudinal and behavioural change as well as influence social capital building [28].

Of particular importance is the recognition of different types of public knowledge and the ways they can be better integrated into policy and decision-making. Wolf and Moser [24] underscore the importance of indigenous knowledge in various locations with differing community ways of life and values and find that indigenous knowledge must be better integrated and reflected in scientific evaluations of climate change. To overcome social barriers to learning and engagement, scientific knowledge should be clear and understandable for stakeholders and incorporated with individual, local, and traditional knowledge to improve particularly active public engagement [70]. This kind of engagement can lead to behaviour change to improve climate adaptation responses [3, 22, 24, 57, 62].

\subsection{Effective climate change adaptation through public knowledge and engagement}

Wolf and Moser [24] point out that the relationship between public knowledge and engagement in climate change adaptation has been the focus of research and policy for nearly three decades. However, the findings of this review indicate that the study of public engagement and its relationship to resilience and climate change adaptation needs to be expanded through further research using diverse international cases. Consistent with the broader literature, our research has found public engagement to be an influential factor in raising awareness and community development that collectively increase government capacity particularly in the local scale for implementing risk reduction strategies $[24,57,60,62,65,69,70,76]$. Studies by Burnside-Lawry and Carvalho [76] and Madumere [4] show the important role of motivation in participating in innovative strategies to reduce climate change impacts. Lorenzoni et al. [21], however, suggest that even with enough information, knowledge, and a high level of motivation economic and social barriers (such as lack of institutional support and infrastructure) can still impede engagement. 
A combination of bottom-up and top-down approaches are proposed in the literature to overcome the barriers to public engagement and generate better knowledge and awareness amongst the stakeholders [63, 82, 85, 95, 96]. Bottomup approaches are more effective as they make communities more active and create space for empowerment. Sherman and Ford [85], however, suggest that in the initial stages, a top-down approach can support communities to generate awareness and interest among them for further engagement in the projects.

Public participation performs an important function in legitimizing government policy and decisions, especially for controversial issues such as climate change [3,97-100]. Geiger et al. [101] suggest that just as infrequent exposure to climate change is likely to lower its salience and inhibit behavioural responses, increasing the public's exposure will foster increased engagement. Luís et al.'s [68] study to understand and promote stakeholder engagement in local climate adaptation planning from a psychosocial perspective using three European case studies found that attitudes towards engagement and knowledge on policy making process were more relevant to explaining levels of public engagement than knowledge on and attitude towards climate change.

Several studies reported a positive linkage between public participation and effective adaptation strategies or policies [63, 83, 102]. Only one article, Burton and Mustelin [3], question whether greater public participation is the key to success in planning for climate change and find no evidence that the presumed benefits of greater participation are realised in practice in their case study of South East Queensland, Australia. Numerous studies illustrate the link between higher levels of participation in the IAP ${ }^{2}$ spectrum detailed in Table 1 (involve, collaborate, and empower) and better adaptation policies and outcomes. Wiseman et al.'s [60] (p. 144) study on exploring the effectiveness of community engagement strategies in improving climate mitigation and adaptation outcomes in Victoria, Australia, found that effective climate mitigation and adaptation strategies require carefully planned and implemented community engagement "for achieving deep, broad and sustainable changes in the actions and behaviours of communities, industries, households and individuals". Research into participation in volunteer environmental monitoring activities not only provided individual benefits such as increasing personal knowledge and community awareness but also community-level outcomes including changing attitudes and behaviours, building social capital, and most importantly improved natural resource management and policies [28]. Sherman and Ford's [85] evaluation of 18 adaptation projects in developing nations revealed that bottom-up community stakeholder engagement in project design and implementation led to higher effectiveness, efficiency, equity, flexibility, legitimacy, sustainability, and replicability compared to top-down approaches. In summary, these projects achieved: more project objectives within the stated timeframe and scale; increased time- and/or resource-efficiency; had a more explicit emphasis on marginalized populations; tailored project methods and activities to the local context; and had high levels of transparency of project activities, strong communication with local stakeholders, and the potential to scale up and implement the project in another location. McNamara's [73] study examining community-based climate-change adaptation projects in the Pacific similarly concluded that local environmental knowledge was successfully integrated throughout the project cycle and the local community was actively involved in the project planning, decision-making, and activities in successful projects. A climate change scenario planning exercise in Alaska also showed that participation can spread knowledge, empower communities, and contribute to more robust decisions by considering local context [11]. In contrast, researchers pointed to limited community engagement in Ontario wind project approvals as a possible reason for the ongoing resistance to the projects [54].

\section{Conclusions}

Dealing effectively with the impacts of climate change requires collaboration between the public, experts, and governments to develop and implement appropriate policy responses. This study reviewed the literature regarding the relationship between public awareness, knowledge, and engagement and how these can improve climate change adaptation policy. The SQLR method was used to analyse 78 studies. Overall, the review showed that the number of articles in this field has greatly increased in recent years particularly in developed countries in North America and Europe. However, further studies are required to address the knowledge gap particularly in developing countries. The limitations of the study include language and exclusion of grey literature. In addition, as in other forms of reviews, we had to rely on what the authors of the primary literature chose to report in each study. Most of these studies were conducted to address different research questions and focused their reporting accordingly. This may have resulted in 
the underestimation of the percentages we reported as lack of reporting does not necessarily mean the absence of these items in the cases studied.

The findings of this review suggest that climate change communication is crucial to improve knowledge and awareness, which will increase engagement with climate policy, that in turn can improve policies and outcomes. Many studies indicate that there is a strong link between active engagement and awareness and knowledge of climate risks, and that engagement can change attitudes as well as have a positive impact on behaviour. The lack of knowledge and awareness is also an important barrier to passive engagement. The findings of this review indicated that among five levels of public participation the lowest three levels (inform, consult and involve) are used more often than the two higher levels (collaborate and empower). Since public support is needed to improve climate change policies and plans, more research needs to focus on the public engagement process to identify effective strategies for improving active and higher levels of engagement that can help to build community resilience. In addition, the importance of the media's role to support public participation at all levels is inevitable and needs to be considered more in further research. Communities have a crucial role to play in all steps of the policy cycle and the literature shows public engagement is necessary to build knowledge, awareness, and capacity for behavioural change during policy development and decision-making. The literature highlighted that key barriers to public engagement were lack of motivation and resistance to power redistribution. Inadequacies of poor communities' political socioeconomic infrastructure and knowledge base and distrust were the main issues for governance of the sustained participation. In order to overcome these barriers during the decisionmaking process, further studies are needed on the combination of bottom-up and top-down approaches during the decision-making process.

The reviewed studies indicate the importance of individual, local, and traditional knowledge and their integration with scientific knowledge to support local communities in climate change adaptation. However, more research should be conducted to support local governments to motivate communities for engagement in climate change adaptation planning. Finally, the literature shows that among the seven policy instruments, advocacy (information sharing), networks (the development of social capital), and behavioural economics (increasing motivation toward economic behaviour) are more often used in climate change response than other types of policy instruments. More research is needed to enhance the use of these instruments during climate change adaptation action. The ultimate goal is to identify how to build more sustainable and resilient societies.

Acknowledgements We thank the anonymous reviewers for their constructive and helpful feedback.

Authors' contributions Conceptualization, methodology, investigation, formal analysis, writing - original draft preparation, visualization: FSK. Conceptualization, methodology, writing—review and editing, supervision: AD-H, MH, ET. All authors read and approved the final manuscript.

Funding Not applicable.

Data and Code availability Not applicable.

Declarations

Competing interests Not applicable.

Open Access This article is licensed under a Creative Commons Attribution 4.0 International License, which permits use, sharing, adaptation, distribution and reproduction in any medium or format, as long as you give appropriate credit to the original author(s) and the source, provide a link to the Creative Commons licence, and indicate if changes were made. The images or other third party material in this article are included in the article's Creative Commons licence, unless indicated otherwise in a credit line to the material. If material is not included in the article's Creative Commons licence and your intended use is not permitted by statutory regulation or exceeds the permitted use, you will need to obtain permission directly from the copyright holder. To view a copy of this licence, visit http://creativecommons.org/licenses/by/4.0/.

\section{Appendix}

See Tables 7 and 8. 
Table 7 Literature review categories and sources

\begin{tabular}{|c|c|}
\hline Category [source] & Subcategory \\
\hline Document information & $\begin{array}{l}\text { Document type } \\
\text { Author/s } \\
\text { First author location } \\
\text { Year of publication } \\
\text { Title }\end{array}$ \\
\hline Journal information & $\begin{array}{l}\text { Journal discipline (based on Ulrich's Web Global } \\
\text { Serials Directory) }\end{array}$ \\
\hline Case study locations & $\begin{array}{l}\text { Country/s of study } \\
\text { Continents }\end{array}$ \\
\hline Research design [103] and Methods [104] & $\begin{array}{l}\text { Research design } \\
\text { Data collection methods } \\
\text { Data analysis methods }\end{array}$ \\
\hline Awareness and type of knowledge in climate change & $\begin{array}{l}\text { Importance of awareness } \\
\text { Scientific knowledge } \\
\text { Individual knowledge } \\
\text { Local knowledge } \\
\text { Traditional knowledge }\end{array}$ \\
\hline Dimensions of active engagement [21] & $\begin{array}{l}\text { Cognitive } \\
\text { Affective } \\
\text { Behavioural }\end{array}$ \\
\hline Dimensions of passive engagement [20] & $\begin{array}{l}\text { Cognitive } \\
\text { Affective }\end{array}$ \\
\hline Participation focus & $\begin{array}{l}\text { Adaptation } \\
\text { Mitigation } \\
\text { Both } \\
\text { General }\end{array}$ \\
\hline Timing of public participation & $\begin{array}{l}\text { Policy development }{ }^{\mathrm{a}} \\
\text { Decision-making } \\
\text { Implementation } \\
\text { Monitoring and assessment }\end{array}$ \\
\hline Level of public participation [19] & $\begin{array}{l}\text { Inform } \\
\text { Consult } \\
\text { Involve } \\
\text { Collaborate } \\
\text { Empower }\end{array}$ \\
\hline Barriers to public participation in climate change $[18,86]$ & $\begin{array}{l}\text { For organizations and communities } \\
\text { For governance of sustained participation }\end{array}$ \\
\hline Policy instruments [15] & $\begin{array}{l}\text { Advocacy } \\
\text { Network } \\
\text { Money } \\
\text { Government action } \\
\text { Law } \\
\text { Behavioural economics } \\
\text { Narrative }\end{array}$ \\
\hline
\end{tabular}

${ }^{\text {a }}$ Policy development refers to the first four stages of the policy cycle: identifying issues, policy analysis, policy instruments and consultation 


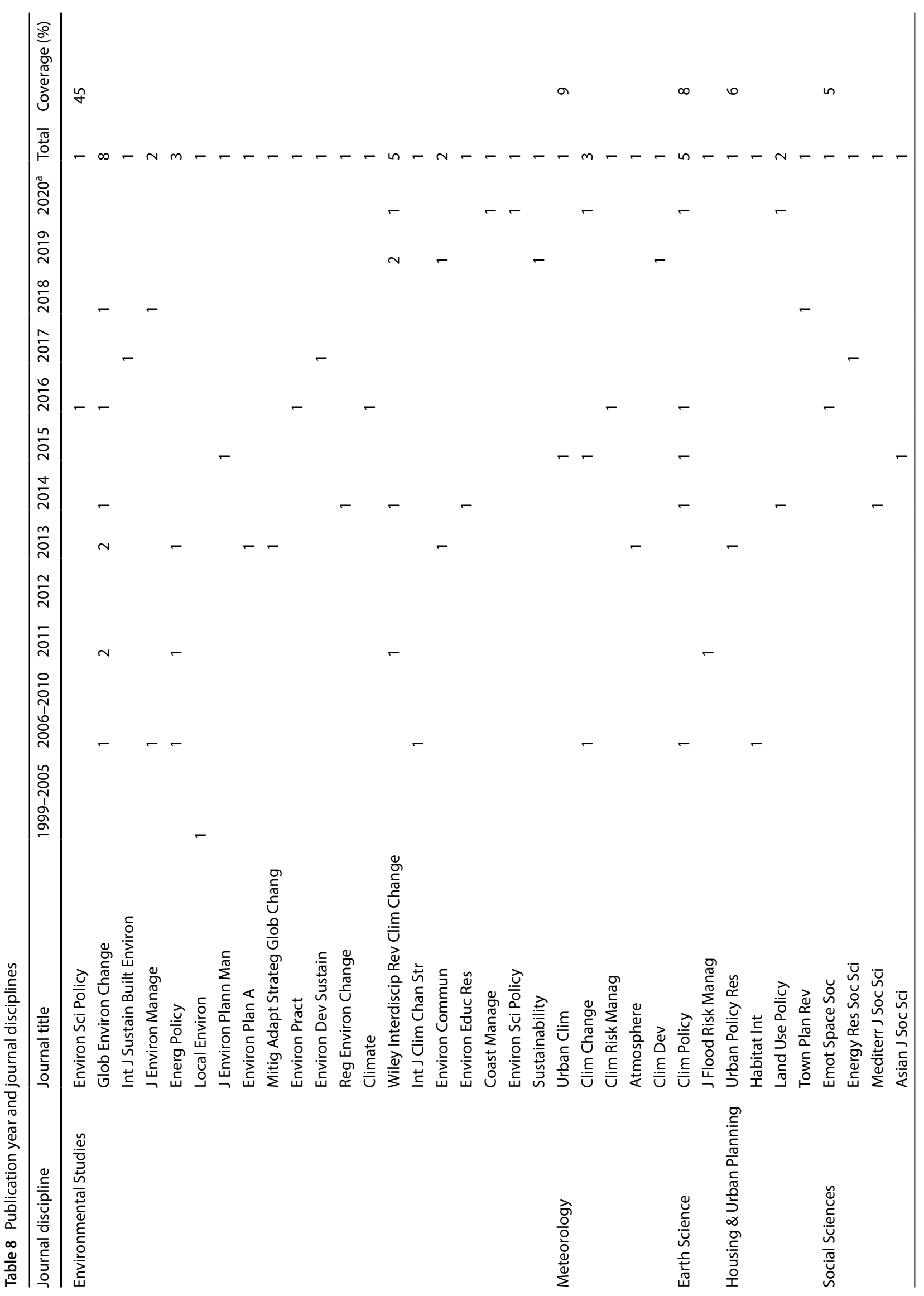




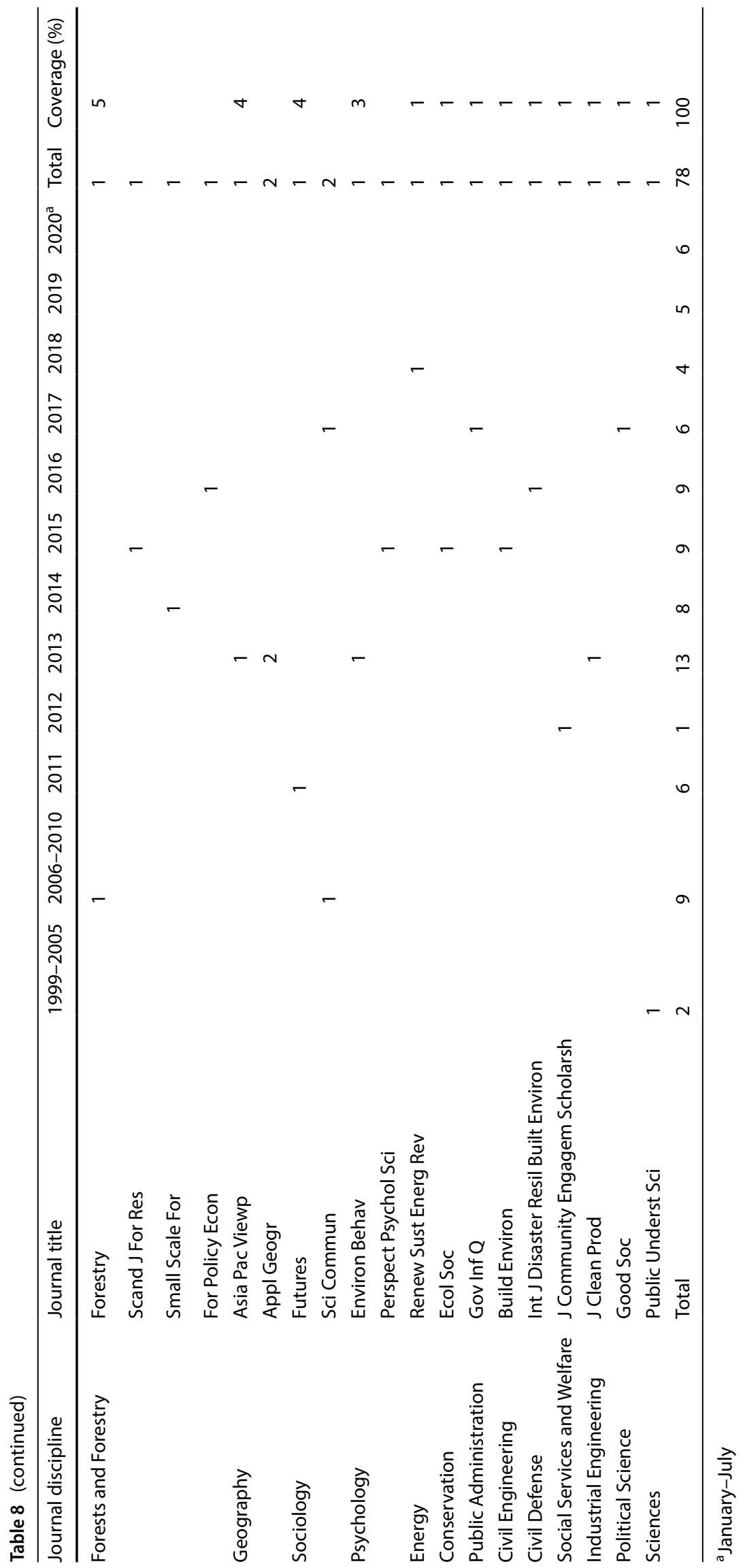




\section{References}

\section{Articles included in the Systematic Quantitative Literature Review are noted with an asterisk. While references [105-119] are not directly quoted in the article they are included in all quantitative analysis}

1. Intergovernmental Panel on Climate Change (IPCC). Climate Change 2014 Synthesis Report Summary for Policymakers. Contribution of Working Groups I, II and III to the Fifth Assessment Report of the Intergovernmental Panel on Climate Change; 2014.

2. * Bernauer T, Gampfer R, Meng T, Su YS. Could more civil society involvement increase public support for climate policy-making? Evidence from a survey experiment in China. Glob Environ Change. 2016;40:1-12.

3. *Burton P, Mustelin J. Planning for climate change: Is greater public participation the key to success? Urban Policy Res. 2013;31(4):399-415.

4. * Madumere N. Public enlightenment and participation-a major contribution in mitigating climate change. Int J Sustain Built Environ. 2017;6(1):9-15.

5. *Serrao-Neumann S, Harman B, Leitch A, Low CD. Public engagement and climate adaptation: Insights from three local governments in Australia. J Environ Plann Man. 2015;58(7):1196-216.

6. Vigneswaran S, Leelamani A, Divya S, Divya K. Communicating climate change importance through interactive multimedia frame work for promoting education and effective public awareness on climate change. Int J Appl Environ Sci. 2017;12(3):409-20.

7. Productivity Commission. Barriers to effective climate change adaptation: Productivity Commission draft report. Melbourne: Productivity Commission; 2012.

8. Owen G. What makes climate change adaptation effective? A systematic review of the literature. Glob Environ Change. 2020;62:102071.

9. IPCC. Climate change 2007: impacts, adaptation and vulnerability. Contribution of Working Group II to the Fourth Assessment Report of the IPCC; 2007.

10. *Bahauddin KM, Rahman N, Hasnine MDT. Public perception, knowledge, and participation in climate change adaptation governance in the coastal region of Bangladesh using the Social Ecological Inventory (SEI) tool. Environ Pract. 2016;18(1):32-43.

11. *Ernst KM, van Riemsdijk M. Climate change scenario planning in Alaska's National Parks: stakeholder involvement in the decision-making process. Appl Geogr. 2013;45:22-8.

12. Lassen I, Pedersen A, Bonnen K, Horsbøl A. Climate change discourses and citizen participation: a case study of the discursive construction of citizenship in two public events. Environ Commun. 2011;5(4):411-27.

13. *Vignola R, Klinsky S, Tam J, McDaniels T. Public perception, knowledge and policy support for mitigation and adaption to Climate Change in Costa Rica: comparisons with North American and European studies. Mitig Adapt Strateg Glob Chang. 2013;18(3):303-23.

14. Kheerajit C, Flor AG. Participatory development communication for natural resources management in Ratchaburi province, Thailand. Procedia Soc Behav Sci. 2013;103:703-9.

15. Althaus CE, Bridgman P, Davis G. The Australian Policy Handbook. 6th ed. Crows Nest, NSW: Allen \& Unwin; 2018.

16. Creighton JL. The public participation handbook: Making better decisions through citizen involvement. San Francisco, CA: John Wiley \& Sons, Incorporated; 2005.

17. Nabatchi T, Amsler LB. Direct public engagement in local government. Am Rev Public Adm. 2014;44(4_suppl):63S-88S.

18. Arnstein SR. A ladder of citizen participation. J Am Inst Plann. 1969;35(4):216-24.

19. International Association for Public Participation (IAP $\left.{ }^{2}\right) I_{A} P^{2}$ Published Resources. 2019. https://www.iap2.org.au/resources/iap2-publi shed-resources/. Accessed 30 October 2020.

20. *Axon S. "The Good Life": engaging the public with community-based carbon reduction strategies. Environ Sci Policy. 2016;66:82-92.

21. *Lorenzoni I, Nicholson-Cole S, Whitmarsh L. Barriers perceived to engaging with climate change among the UK public and their policy implications. Glob Environ Change. 2007;17(3-4):445-59.

22. *Burke M, Ockwell D, Whitmarsh L. Participatory arts and affective engagement with climate change: the missing link in achieving climate compatible behaviour change? Glob Environ Change. 2018;49:95-105.

23. *Sutton SG, Tobin RC. Constraints on community engagement with Great Barrier Reef climate change reduction and mitigation. Glob Environ Change. 2011;21(3):894-905.

24. *Wolf J, Moser SC. Individual understandings, perceptions, and engagement with climate change: insights from in-depth studies across the world. Wiley Interdiscip Rev Clim Change. 2011;2(4):547-69.

25. Mabelis A, Maksymiuk G. Public participation in green urban policy: two strategies compared. Int J Biodivers Sci Ecosyst Serv Manag. 2009;5(2):63-75.

26. Gen S, Wright AC. Policy advocacy organizations: a framework linking theory and practice. J Policy Pract. 2013;12(3):163-93.

27. Coffman J, Beer T. The advocacy strategy framework. Washington, DC: Center for Evaluation Innovation; 2015.

28. *Stepenuck KF, Green LT. Individual- and community-level impacts of volunteer environmental monitoring: a synthesis of peer-reviewed literature. Ecol Soc. 2015;20(3):19.

29. Semali LM, Kincheloe JL. What is indigenous knowledge? Voices from the academy. 1st ed. New York: Falmer Press; 1999.

30. Olsson P, Folke C. Local ecological knowledge and institutional dynamics for ecosystem management: a study of Lake Racken Watershed. Sweden Ecosystems. 2001:4(2):85-104.

31. Craig D, Davis MR. Ethical relationships for biodiversity research and benefit-sharing with indigenous peoples. Macquarie J Int Comp Environ Law. 2005;2(2):31-74.

32. Mazzocchi F. Western science and traditional knowledge: despite their variations, different forms of knowledge can learn from each other. EMBO Rep. 2006;7(5):463-6.

33. Barnett J, Campbell J. Climate change and small island states: Power, knowledge, and the South Pacific. London; Washington, DC: Earthscan; 2010. 
34. Berkes F. Traditional ecological knowledge in perspective. In: Inglis JT, editor. Traditional ecological knowledge: concept and cases. Ottawa: International Program on Traditional Ecological Knowledge; 1993. p. 1-9.

35. Riedlinger D. Community-based assessments of change: contributions of Inuvialuit knowledge to understanding climate change in the Canadian arctic (Master's thesis); 2001. https://mspace.lib.umanitoba.ca/handle/1993/1940

36. *Bulkeley H. Common knowledge? Public understanding of climate change in Newcastle. Australia Public Underst Sci. 2000;9(3):313-34.

37. Cash DW, Clark WC, Alcock F, Dickson NM, Eckley N, Guston DH, Jäger J, Mitchell RB. Knowledge systems for sustainable development. P Natl Acad Sci. 2003;100(14):8086-91.

38. Lemos MC, Morehouse BJ. The co-production of science and policy in integrated climate assessments. Glob Environ Change. 2005;15(1):57-68.

39. Combs JG, Ketchen DJ, Crook R, Roth PL. Assessing cumulative evidence within 'macro' research: why meta-analysis should be preferred over vote-counting. J Manage Stud. 2011;48:178-97.

40. Petticrew M. Systematic reviews from astronomy to zoology: myths and misconceptions. BMJ. 2001;322:98-101.

41. Petticrew M, Roberts H. Systematic reviews in the social sciences: a practical guide. Oxford: Blackwell Publishing; 2006.

42. Haddaway NR, Macura B. The role of reporting standards in producing robust literature reviews. Nat Clim Change. 2018;8(6):444-7.

43. Haddaway NR, Bilotta GS. Systematic reviews: separating fact from fiction. Environ Int. 2016;92:578-84.

44. Haddaway NR, Bethel A, Dicks LV, Koricheva J, Macura B, Petrokofsky G, Pullin AS, Savilaakso S, Stewart GB. Eight problems with literature reviews and how to fix them. Nat Ecol Evol. 2020;12:1-8.

45. Pickering C, Byrne J. The benefits of publishing systematic quantitative literature reviews for PhD candidates and other early-career researchers. High Educ Res Dev. 2014;33(3):534-48.

46. Wortley L, Hero JM, Howes M. Evaluating ecological restoration success: a review of the literature. Restor Ecol. 2013;21(5):537-43.

47. Howes M, Wortley L, Potts R, Dedekorkut-Howes A, Serrao-Neumann S, Davidson J, Smith T, Nunn P. Environmental sustainability: A case of policy implementation failure? Sustainability. 2017;9(2):165.

48. Boulton C, Dedekorkut-Howes A, Byrne J. Factors shaping urban greenspace provision: a systematic review of the literature. Landsc Urban Plan. 2018;178:82-101.

49. Dedekorkut-Howes A, Torabi E, Howes M. When the tide gets high: A review of adaptive responses to sea level rise and coastal flooding. J Environ Plann and Man. 2020;63:2102-43.

50. Moher D, Liberati A, Tetzlaff J, Altman DG, The PRISMA Group. The PRISMA Group Preferred reporting items for systematic reviews and meta-analyses: the PRISMA statement. PLoS Med. 2009;6(7):1000097.

51. ABC News. Reinsurer estimates 2012's disasters cost $\$ 160$ b. 3 January 2013. https://www.abc.net.au/news/2013-01-04/reinsurer-estim ates-2012s-disasters-cost-160b/4452288. Accessed 11 February 2021.

52. IPCC. Managing the risks of extreme events and disasters to advance climate change adaptation. Field CB, Barros V, Stocker TF, Qin D, Dokken DJ, Ebi KL, Mastrandrea MD, Mach KJ, Plattner G-K, Allen SK, Tignor M, Midgley PM, editors. Cambridge: Cambridge University Press; 2012.

53. *Pietrapertosa F, Khokhlov V, Salvia M, Cosmi C. Climate change adaptation policies and plans: a survey in 11 South East European countries. Renew Sust Energ Rev. 2018;81:3041-50.

54. *Jami AA, Walsh PR. From consultation to collaboration: a participatory framework for positive community engagement with wind energy projects in Ontario, Canada. Energy Res Soc Sci. 2017;27:14-24.

55. *Ryan K. Incorporating emotional geography into climate change research: a case study in Londonderry, Vermont, USA. Emot Space Soc. 2016;19:5-12.

56. ${ }^{*}$ Chu E, Anguelovski I, Carmin J. Inclusive approaches to urban climate adaptation planning and implementation in the Global South. Clim Policy. 2016;16(3):372-92.

57. *Bohensky EL, Kirono DGC, Butler JRA, Rochester W, Habibi P, Handayani T, Yanuartati Y. Climate knowledge cultures: stakeholder perspectives on change and adaptation in Nusa Tenggara Barat, Indonesia. Clim Risk Manag. 2016;12:17-31.

58. *Alamgir M, Pretzsch J, Turton SM. Climate change effects on community forests: finding through user's lens and local knowledge. Small-scale For. 2014;13(4):445-60.

59. *Thaker J, Howe P, Leiserowitz A, Maibach E. Perceived collective efficacy and trust in government influence public engagement with climate change-related water conservation policies. Environ Commun. 2019;13(5):681-99.

60. *Wiseman J, Williamson L, Fritze J. Community engagement and climate change: learning from recent Australian experience. Int J Clim Chan Str. 2010;2(2):134-47.

61. *Leonard S, Parsons M, Olawsky K, Kofod F. The role of culture and traditional knowledge in climate change adaptation: insights from East Kimberley, Australia. Glob Environ Change. 2013;23(3):623-32.

62. *Ross H, Shaw S, Rissik D, Cliffe N, Chapman S, Hounsell V, Udy J, Trinh NT, Schoeman J. A participatory systems approach to understanding climate adaptation needs. Clim Change. 2015;129(1-2):27-42.

63. *Amaru S, Chhetri NB. Climate adaptation: Institutional response to environmental constraints, and the need for increased flexibility, participation, and integration of approaches. Appl Geogr. 2013;39:128-39.

64. *Figueiredo P, Perkins PE. Women and water management in times of climate change: Participatory and inclusive processes. J Clean Prod. 2013;60:188-94.

65. *Cloutier G, Joerin F, Dubois C, Labarthe M, Legay C, Viens D. Planning adaptation based on local actors' knowledge and participation: a climate governance experiment. Clim Policy. 2015;15(4):458-74.

66. *Sheppard SRJ, Shaw A, Flanders D, Burch S, Wiek A, Carmichael J, Robinson J, Cohen S. Future visioning of local climate change: a framework for community engagement and planning with scenarios and visualisation. Futures. 2011;43(4):400-12.

67. *Groot AME, Bosch PR, Buijs S, Jacobs CMJ, Moors EJ. Integration in urban climate adaptation: lessons from Rotterdam on integration between scientific disciplines and integration between scientific and stakeholder knowledge. Build Environ. 2015;83:177-88.

68. *Luís S, Lima ML, Roseta-Palma C, Rodrigues N, Sousa LP, Freitas F, Alves F, Lillebø Al, Parrod C, Jolivet V, Paramana T, Alexandrakis G, Poulos S. Psychosocial drivers for change: understanding and promoting stakeholder engagement in local adaptation to climate change in three European Mediterranean case studies. J Environ Manage. 2018;223:165-74. 
69. * ${ }^{*}$ Chilvers J, Lorenzoni I, Terry G, Buckley P, Pinnegar J, Gelcich S. Public engagement with marine climate change issues: (re)framings, understandings and responses. Glob Environ Change. 2014;29:165-79.

70. *Vulturius G, Gerger SÅ. Overcoming social barriers to learning and engagement with climate change adaptation: experiences with Swedish forestry stakeholders. Scand J For Res. 2015;30(3):217-25.

71. *Pasquier U, Few R, Goulden MC, Hooton S, He Y, Hiscock KM. "We can't do it on our own!"-integrating stakeholder and scientific knowledge of future flood risk to inform climate change adaptation planning in a coastal region. Environ Sci Policy. 2020;103:50-7.

72. *Rahman H, Alam K. Forest dependent indigenous communities' perception and adaptation to climate change through local knowledge in the protected area-a Bangladesh case study. Climate. 2016;4(1):12.

73. *McNamara KE. Taking stock of community-based climate-change adaptation projects in the Pacific. Asia Pac Viewp. 2013;54(3):398-405.

74. *Bruun O, Olwig MF. Is local community the answer? Asian J Soc Sci. 2015;43(6):811-36.

75. *Zuma-Netshiukhwi G, Stigter K, Walker S. Use of traditional weather/climate knowledge by farmers in the South-Western Free State of South Africa: Agrometeorological learning by scientists. Atmosphere. 2013;4(4):383-410.

76. *Burnside-Lawry J, Carvalho L. A stakeholder approach to building community resilience: awareness to implementation. Int J Disaster Resil Built Environ. 2016;7(1):4-25.

77. *Whitmarsh L, Seyfang G, O'Neill S. Public engagement with carbon and climate change: to what extent is the public "carbon capable"? Glob Environ Change. 2011;21(1):56-65.

78. *Ahmed MNQ, Atiqul Haq SM. Indigenous people's perceptions about climate change, forest resource management, and coping strategies: a comparative study in Bangladesh. Environ Dev Sustain. 2019;21(2):679-708.

79. *Dowd AM, Boughen N, Ashworth P, Carr-Cornish S. Geothermal technology in Australia: investigating social acceptance. Energy Policy. 2011;39(10):6301-7.

80. *Sethamo OA, Masika RJ, Harder MK. Understanding the role of crystallizing local shared values in fostering effective community engagement in adaptation planning in Botswana. Clim Dev. 2020;12(5):448-56.

81. *Wamsler C, Alkan-Olsson J, Björn H, Falck H, Hanson H, Oskarsson T, Simonsson E, Zelmerlow F. Beyond participation: When citizen engagement leads to undesirable outcomes for nature-based solutions and climate change adaptation. Clim Change. 2020;158(2):235-54

82. *Nunn PD, Aalbersberg W, Lata S, Gwilliam M. Beyond the core: community governance for climate-change adaptation in peripheral parts of Pacific Island Countries. Reg Environ Change. 2014;14(1):221-35.

83. *Sarzynski A. Public participation, civic capacity, and climate change adaptation in cities. Urban Clim. 2015;14:52-67.

84. *Tompkins EL, Few R, Brown K. Scenario-based stakeholder engagement: incorporating stakeholders preferences into coastal planning for climate change. J Environ Manage. 2008;88(4):1580-92.

85. *Sherman $\mathrm{MH}$, Ford J. Stakeholder engagement in adaptation interventions: an evaluation of projects in developing nations. Clim Policy. 2014;14(3):417-41.

86. * *Sprain L. Paradoxes of public participation in climate change governance. Good Soc. 2017;25(1):62-80.

87. * Jeffers J. Barriers to transformation towards participatory adaptation decision-making: Lessons from the cork flood defences dispute. Land Use Policy. 2020;90:104333.

88. *Scannell L, Gifford R. Personally relevant climate change: the role of place attachment and local versus global message framing in engagement. Environ Behav. 2013;45(1):60-85.

89. *Hügel S, Davies AR. Public participation, engagement, and climate change adaptation: a review of the research literature. Wiley Interdiscip Rev Clim Change. 2020;11(4):645.

90. *Schmidt L, Gomes C, Guerreiro S, O'Riordan T. Are we all on the same boat? The challenge of adaptation facing Portuguese coastal communities: risk perception, trust-building and genuine participation. Land Use Policy. 2014;38:355-65.

91. ${ }^{*}$ Crawford P, Beyea W, Bode C, Doll J, Menon R. Creating climate change adaptation plans for rural coastal communities using deliberation with analysis as public participation for social learning. Town Plan Rev. 2018;89(3):283-304.

92. *Larsen K, Gunnarsson-Östling U. Climate change scenarios and citizen-participation: mitigation and adaptation perspectives in constructing sustainable futures. Habitat Int. 2009;33(3):260-6.

93. *Wibeck V. Enhancing learning, communication and public engagement about climate change-Some lessons from recent literature. Environ Educ Res. 2014;20(3):387-411.

94. Putnam RD. Tuning in, tuning out: the strange disappearance of social capital in America. PS Polit Sci Polit. 1995;28(4):664-83.

95. *Kloprogge P, Van Der Sluijs JP. The inclusion of stakeholder knowledge and perspectives in integrated assessment of climate change. Clim Change. 2006;75(3):359-89.

96. ${ }^{*}$ Ockwell D, Whitmarsh L, O'Neill S. Reorienting climate change communication for effective mitigation: forcing people to be green or fostering grass-roots engagement? Sci Commun. 2009;30(3):305-27.

97. ${ }^{*}$ Chou KT. The public perception of climate change in Taiwan and its paradigm shift. Energ Policy. 2013;61:1252-60.

98. *Few R, Brown K, Tompkins EL. Public participation and climate change adaptation: avoiding the illusion of inclusion. Clim Policy. 2007;7(1):46-59.

99. *Jetoo S. Stakeholder engagement for inclusive climate governance: the case of the city of Turku. Sustainability. 2019;11(21):6080.

100. *Muradova L, Walker H, Colli F. Climate change communication and public engagement in interpersonal deliberative settings: Evidence from the Irish citizens' assembly. Clim Policy. 2020. https://doi.org/10.1080/14693062.2020.1777928.

101. * ${ }^{*}$ Geiger N, Swim JK, Fraser J, Flinner K. Catalyzing public engagement with climate change through informal science learning centers. Sci Commun. 2017;39(2):221-49.

102. *van der Linden S, Maibach E, Leiserowitz A. Improving public engagement with climate change: five "best practice" insights from psychological science. Perspect Psychol Sci. 2015;10(6):758-63.

103. University of Southern California (USC) Library. Type of research designs. 2017. http://libguides.usc.edu/writingguide/researchdesigns Accessed 28 October 2017.

104. Bryman A. Social research methods. 4th ed. Oxford: Oxford University Press; 2012.

105. ${ }^{*}$ Cone J, Rowe S, Borberg J, Goodwin B. Community planning for climate change: Visible thinking tools facilitate shared understanding. J Community Engagem Scholarsh. 2012;5(2):7. 
106. ${ }^{*}$ Cook BR, Overpeck JT. Relationship-building between climate scientists and publics as an alternative to information transfer. Wiley Interdiscip Rev Clim Change. 2019;10(2):570.

107. *Darier É, Schüle R. Think globally, act locally'? Climate change and public participation in Manchester and Frankfurt. Local Environ. 1999;4(3):317-29.

108. *Kauneckis D, Martin R. Patterns of adaptation response by coastal communities to climate risks. Coast Manage. 2020;48:257-74.

109. *'Lacuna-Richman C, Devkota BP, Richman MA. Users' priorities for good governance in community forestry: two cases from Nepal's Terai Region. For Policy Econ. 2016;65:69-78.

110. *Mees HLP, Uittenbroek CJ, Hegger DLT, Driessen PPJ. From citizen participation to government participation: an exploration of the roles of local governments in community initiatives for climate change adaptation in the Netherlands. Environ Policy Gov. 2019;29(3):198-208.

111. *Moser SC. Communicating adaptation to climate change: the art and science of public engagement when climate change comes home. Wiley Interdiscip Rev Clim Change. 2014;5(3):337-58.

112. *Nye M, Tapsell S, Twigger-Ross C. New social directions in UK flood risk management: moving towards flood risk citizenship? J Flood Risk Manag. 2011;4(4):288-97.

113. *Odeku KO, Meyer EL. Knowledge production, community engagement/development and global climate change. Mediterr J Soc Sci. 2014;5(7):671.

114. *Pallett $\mathrm{H}$, Chilvers J. A decade of learning about publics, participation, and climate change: institutionalising reflexivity? Environ Plan A. 2013;45(5):1162-83.

115. *Petrokofsky G, Brown ND, Hemery GE, Woodward S, Wilson E, Weatherall A, Stokes V, Smithers RJ, Sangster M, Russell K, Pullin AS. A participatory process for identifying and prioritizing policy-relevant research questions in natural resource management: a case study from the UK forestry sector. Forestry. 2010;83(4):357-67.

116. *Pina $V$, Torres L, Royo S. Comparing online with offline citizen engagement for climate change: findings from Austria, Germany and Spain. Gov Inf Q. 2017;34(1):26-36.

117. *Raymond CM, Robinson GM. Factors affecting rural landholders' adaptation to climate change: insights from formal institutions and communities of practice. Glob Environ Change. 2013;23(1):103-14.

118. *Rusche TM. The European climate change program: an evaluation of stakeholder involvement and policy achievements. Energy Policy. 2010;38(10):6349-59.

119. *Schweizer S, Davis S, Thompson JL. Changing the conversation about climate change: a theoretical framework for place-based climate change engagement. Environ Commun. 2013;7(1):42-62.

Publisher's Note Springer Nature remains neutral with regard to jurisdictional claims in published maps and institutional affiliations. 